\title{
Immunotherapy with patient-specific antigens selection reduced the metastasis of a cervical cancer patient
}

\author{
Yanyan $\mathrm{Han}^{1 *}$, Jianting Long ${ }^{2}$, Sheng $\mathrm{Ye}^{2}$, Ran $\mathrm{TaO}^{3}$, Dongyun $\mathrm{Wu}^{3}$, Jin $\mathrm{Li}^{3}$, Xiangjun Zhou ${ }^{3}$ \\ From 30th Annual Meeting and Associated Programs of the Society for Immunotherapy of Cancer (SITC 2015) \\ National Harbor, MD, USA. 4-8 November 2015
}

\begin{abstract}
Background
Cervical cancer is the second most common gynecologic malignant tumor, and is frequently associated with human papilloma virus (HPV) infection. Patients with vascular invaded tumors are more likely to develop metastatic disease after radical resection of primary tumor. Current treatment for metastatic cervical cancer is not effective. In 2011, a patient was diagnosed as $\mathrm{HPV}^{+}$cervical squamous cell carcinoma with vascular invasion. 33 months after radical resection, and subsequent adjuvant chemoradiation therapy, metastasis was detected on the right sacroiliac joint. Given that standard therapy was unsuccessful, the patient was treated with MASCT (Multiple Antigen Stimulating Cellular Therapy), which is composed of multiple tumor antigen pulsed dendritic cells (DCs) and autologous $\mathrm{T}$ lymphocytes activated by these DCs.
\end{abstract}

\section{Methods}

Monocytes from the patient's PBMCs were differentiated into immature dendritic cells (iDCs) and then pulsed with multiple synthetic peptide antigens including tumor-associated antigens and HPV specific antigens. The semi-mature DCs were further stimulated by diverse TLR ligands to differentiate into mature DCs (mDCs). Half of these mDCs were subcutaneous injected to the patient, and the other half were co-cultured with the maintaining non-adherent $\mathrm{T}$ cells for another 7-9 days before infusion back to the patient.

\section{Results}

The mDCs expressed high level of HLA-DR, CD80, CD86, CD83, and CCR7 on the surface. And the activated T cells

'Department of Infectious Diseases, Nanfang Hospital, Southern Medical University, Guangzhou, China

Full list of author information is available at the end of the article were almost exclusively $\mathrm{CD}^{+} \mathrm{T}$ cells, with a major part being $\mathrm{CD}^{+} \mathrm{CD}^{+}$cells and insignificant amounts of regulatory $\mathrm{T}$ cells. After local irradiation, the patient was given repeating MASCT treatments every 1-2 months. After 3 times MASCT treatments (6 months after metastasis), the patient was evaluated as partial remission by whole body bone SPECT (single-photon emission computed tomography). Following additional 5 times MASCT treatments (12 months after metastasis), the patient remained partial remission. Moreover, specific responses against tumor antigens were detected in the patients' PBMCs by IFNg ELISPOT assay, such as telomerase, p53, CEA, and HPV18/58 (Figure 1). Based on patient's specific immune response, we therefore adjusted her antigen peptide pool by saving the antigens, which had induced specific responses and removed the peptides that did not. The adjusted antigen pool clearly further boosted the specific responses (Figure 2).

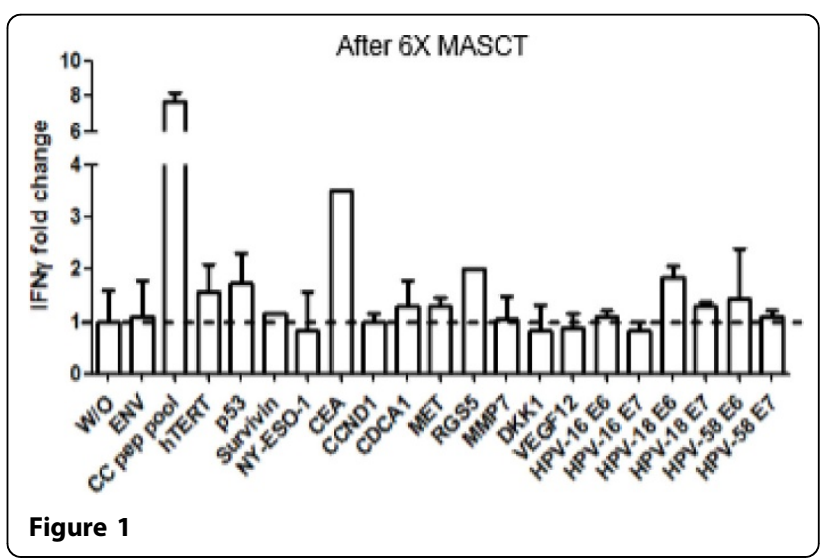




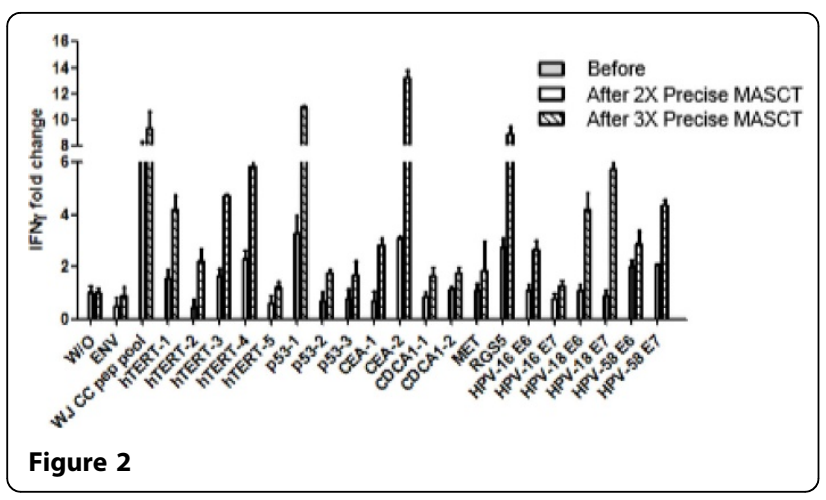

\section{Conclusion}

Our study provides MASCT with as a safe treatment, which has reduced the metastasis of the cervical cancer patient. Moreover, tumor antigens specific $\mathrm{T}$ cell responses could be robustly raised in cervical cancer patients after MASCT treatment, and were even further boosted after patient-specific antigens selection.

\section{Authors' details}

${ }^{1}$ Department of Infectious Diseases, Nanfang Hospital, Southern Medical University, Guangzhou, China. ${ }^{2}$ Cell Immunotherapy Center, Dept. of Medicinal Oncology, The First Affiliated Hospital of SUN Yat-Sen University, Guangzhou, China. ${ }^{3}$ SYZ Cell Therapy Co., Shenzhen, China.

Published: 4 November 2015

doi:10.1186/2051-1426-3-S2-P385

Cite this article as: Han et al:: Immunotherapy with patient-specific antigens selection reduced the metastasis of a cervical cancer patient. Journal for ImmunoTherapy of Cancer 2015 3(Suppl 2):P385.
Submit your next manuscript to BioMed Central and take full advantage of:

- Convenient online submission

- Thorough peer review

- No space constraints or color figure charges

- Immediate publication on acceptance

- Inclusion in PubMed, CAS, Scopus and Google Scholar

- Research which is freely available for redistribution

Submit your manuscript at www.biomedcentral.com/submit 